\title{
Twitter as Popular Journalistic Platform - Similarities and Differences Between Jutarnji List and Večernji List
}

Preliminary communication _ DOI 10.22522/cmr20160213 _ received on 22 October 2016 UDK 070(05)"520.1":004.738

\section{Leali Osmančević}

Department of Communication Sciences, Catholic University of Croatia, Croatia.

Email: leali.osmancevic@unicath.hr

\section{Abstract}

The article deals with Twitter as a popular platform for media and journalists. Journalism, as a profession, is now in the $21^{\text {st }}$ century even more accessible to all media audiences mainly because of the rapid development of social networks and mobile media. Twitter is one of the most popular social platforms, and microblogging services and a large number of media and journalists have their official Twitter accounts through which they share the latest news and media content as well as connect with their audience on a daily basis. Twitter has a lot of advantages in the context of journalism, but it is important to firstly learn how to use it in a professional and most beneficial way. The article also presents results of research whose main goal was to determine ways of communicating and possible similarities and differences between two Croatian daily newspapers, Jutarnji list and Večernji list, on Twitter.

Keywords: social networks, Twitter, journalism, daily newspapers, Jutarnji list, Večernji list 


\section{Introduction}

The rapid development of new communication technologies caused new forms of communication among users. The most popular platforms for information exchange in the online world are social networks. The possibilities of online media and social networks are numerous and mostly very positive. Users have easy and fast access to information and opportunities for the exchange of information. Online media and new technologies have created large, diverse and high-quality platforms, not only for receiving and sharing information, but also for networking, learning and fun. The prevalence and popularity of social networks has resulted in an increasing number of users around the world. According to a recent survey conducted by the Pew Research Center (2016), the majority of U.S. adults, $62 \%$ of them, obtain news via social networks. Results show that 70\% of all Reddit users, $66 \%$ of Facebook users, and 59\% of Twitter users obtain news through those social networks (Pew Research Center, 2016).

Social networks have become an essential part of everyday life and an integral part of the communication process among users. According to the national report (Statista, 2016) on the use of social networks in the world published in April this year, it is estimated that the number of users reached 2 billion and this figure is increasing mainly because of the frequency of access to social networks via smartphones and mobile media. One of the most popular and most widely used social networks is certainly Twitter - a social network that was formed in 2006 and last year reported more than 600 million registered users. Posts on Twitter are called tweets and are limited to 140 characters which is the main reason for becoming a microblogging platform (Dwyer, Fraser, 2016, p. 80). Twitter is also popular because of the hashtags (\#) with which users can emphasize certain terms. Hashtags became available to users in 2007 and they are a useful tool for the aggregation of tweets on a specific topic which can lead to discussion among users (Bruns, Burgess, 2011, as cited in Dwyer, Fraser, 2016, p. 81).

Today, journalism as a profession is unthinkable without social networks. Almost all media have become even closer and more accessible to their users through their profiles on social networks. There is also a large number of journalists who are more exposed to users through their profiles on social networks. Through social networks, all media can determine their own way of communication directed to users. This paper will present the results of the content analysis of tweets posted by two Croatian daily newspapers, Jutarnji list and Večernji list. The 
main goal of the research was to determine ways of communication of Jutarnji list and Večernji list via Twitter. The results will also show similarities and differences in their communication via Twitter as a tool for publishing and sharing information and also the positive and negative features that it brings.

\section{New communication technologies and journalism}

Journalism as a profession is even more accessible to its audience because of the numerous and diverse characteristics of online media and social networks. Journalism is facing a number of challenges, mainly in the selection of information that will be offered to users. Media is going through constant change since the invention of the internet. New communication technologies with their availability in some way threaten the authority of the media.

Availability of new communication technologies threatens the authority of the media in some way. Users can obtain all information with just one click, and news about some event is available almost instantly. Moreover, one of the characteristics of online media platforms and its content is "spreadability" which can be defined as a form of a technical resource which allows faster and easier circulation of specific content (Jenkins, Ford, Green, 2013, p. 4).

Online media also affect the sources of information that are one of the foundations of journalism. A well balanced and professional journalistic approach at it source requires full commitment and objective showing of all sides of an event so that users could get a broader picture of the subject that the journalist is writing or reporting about (Malović, 2005, as cited in Labaš, Osmančević, 2014, p. 59). Sources are the ones who give credibility to news (Reich, 2011, as cited in Artwick, 2014, p. 1112) and that is the reason why some journalistic texts cannot be considered as relevant, if there is no high-quality source of information.

The work of journalists is in some way conditioned by the technology that is available. Some authors argue that, despite increasingly frequent budget cuts, media journalists are expected to work faster and more than before, and are forced to produce a greater amount of content with a lower budget (McChesney, Nichols, 2010, as cited in Barnard, 2014, p. 191). Although the online media provide more speed and more accessible information, they do not guarantee the quality, objectivity and professionalism especially when it comes to the selection of 
information and communication with the audience.

Online media have enabled greater interactivity between the editors, journalists and audience. Media content that is posted via online media and is very interactive and encourages the audience to actively participate is much more successful than content that is presented without any interactive audio-visual material (Chung, 2008; Chung, Yoo, 2008, as cited in Armstrong, Gao, 2010, p. 220). New communication technologies have enabled journalism to communicate with the audience and produce media content in some new ways. In order to influence the audience more effectively, journalists are creating content for online media that can gain more attention because attention became "a form of power used to spread a particular message and influence others" (Hermida, 2015, p. 1). Using online media in journalism has its advantages and disadvantages that may result in the erosion of the profession. However, online media could be a tool for improvement of the traditional journalist-audience relationship, mainly because of the participatory culture that directly affects promotion and distribution of media content (Jenkins, Ford, Green, 2013, p. 211). Changes in journalism caused by new communication technologies are also very frequent among researchers because many of them were dealing with four major aspects of change which included alterations in editorial work, practice of news gathering, faster production of content and convergence of traditional and online media (Mitchelstein, Boczkowski, 2009, p. 568).

Media literacy is one of the most necessary competencies of citizens in the $21^{\text {st }}$ century. The ability to critically evaluate media and its content is inevitable for any active citizenship that has its foundations in democracy, credibility and responsibility. Media literacy is particularly necessary in the context of online media, especially social networks. Media literacy became one of the $21^{\text {st }}$ century's literacies mainly because it represents the social skills and competencies which are forming new ways of information processing as well as the level of interactivity with other users and participation within the online media society (Jenkins et al., 2009, p. 103). Media literacy is also inevitable for the upbringing of new generations of children, their parents, educators, teachers and ultimately the media. In the last few years, media literacy is the subject of numerous discussions, research and international projects such as ANS TRANSLIT, COST ISO906, EAVI or EMEDUS (Car, Turčilo, Matović, 2015). Media literacy enables all users to understand, analyse and critically think about media and media content and enables users to independently create high-quality media content (UNESCO, 1999). 


\subsection{Mobile media}

Mobile media also contributed to even greater availability of information and became the subject of numerous scientific studies in particular due to its multifunctionality and the role they play in the daily lives of users (Haddon, 2013, p. 2). The development of mobile media caused the development of research that analysed different aspects of the impact of mobile media. One of the first elaborated researches was published in the book by Rich Ling, entitled “The mobile connection” (Ling, 2004, as cited in Goggin, 2013, pp. 83-84).

Extensive research on the habits and frequency of use of mobile media among teenagers in the United States was conducted by the Pew Research Center last year. According to the results available in the official report (Pew Research Center, 2015), mobile media are extremely popular among the younger population profile. Mobile phones are being actively used by $88 \%$ of young people while smartphones are used by $73 \%$ of young people. Only a third of users have older models of mobile phones without Internet access because of socioeconomic reasons. Laptops are owned and actively used by $87 \%$ of young people and $58 \%$ use tablets. It is interesting that a high $46 \%$ out of the $58 \%$ of young people who have and use tablets come from rich families that have high annual income measured by the parameter of annual income per household members. Also according to these results, girls use tablets more often than boys who prefer laptops and PCs. The European Commission's study conducted in 2015 in seven countries, which included Belgium, the Czech Republic, Finland, Russia, Italy, Germany and the United Kingdom, analysed the habits of using new mobile media and the role they play in the lives of children 0-8 years old, their parents and family members. According to the total results for all countries, the highest percentage of people use tablets and smartphones for searching or following content they are interested in (Chaudron, 2015).

The role of mobile media in the lives of children and young people in particular is interesting because children are beginning to use mobile media at an earlier age. Because of their relatively easy and simple usage, children can use them in numerous different possibilities for searching or viewing content that mobile media offer. Youth and later adult people use mobile media at an early age, which they began to develop their first habits and experiences of using mobile media. Knowledge that they received as children continuously develops and grows as they are growing and becoming adults (Crawford, 2006, as cited in Goggin, 2013, pp. 85-86). 


\subsection{Twitter}

Twitter has become one of the tools of journalism, and it is almost impossible to find a media that does not have an official Twitter account. Twitter is specific for its asymmetry in followers because users can follow whoever they want but it does not mean that same users will follow them back (Gruzd, Wellman, Takhteyev, 2011, p. 1296). Twitter is also known for emphasizing key terms used in a tweet via hashtags that enable users to collect similar tweets and their subjects according to the frequency of use and relevance. In this way, users can quickly and easily have insight into a wide range of tweets that are connected with specific topics (Bruns, Highfield, Lind, 2012, p. 23). Hashtags also give users the possibility of public debate especially when it comes to current and striking events (Highfield, Lind, 2012, p. 24). Although Twitter is known as a social network or social media, by definition it is also a microblogging service, mainly because of the tweets - messages limited to 140 characters (Gruzd, Wellman, Takhteyev, 2011, p. 1296).

Using Twitter in journalism has many advantages, Firstly, it can be a very useful tool for monitoring current events, interviews or simply the promotion of media content (Kirkpatrick, 2008, as cited in Brautović, 2011, p. 62). Also, when it comes to current events and breaking news, Twitter is useful for its speed but also the shortness of information provided in one tweet (Farhi, 2009, as cited in Brautović, 2011, p. 62). Apart from the inevitable promotion of media content, Twitter in journalism is often used as a tool for keeping up with current events and tweet about them instantly which allows an almost instant response from the audience (David, 2010, p. 93).

Another advantage of using Twitter in journalism is the possibility of forwarding or re-tweeting posts. Because of that, current and often forwarded tweets can become viral content which increases promotion and the possibility of a larger number of followers (Brautović, 2011, p. 63). Tweeting about topics that are related to some social issues are often retweeted mainly because of the benefits of spreading the news to new audiences as well as commenting on it and publicly sharing opinion (Marwick, Boyd, 2011, as cited in Veltri, 2012, p. 835).

The benefits of Twitter in journalism have great potential which can result in a large range and wide visibility of content. Numerous Croatian media, especially the major ones, actively use Twitter. In that way they are allowing users faster access to their information and media 
content but also connecting with their employees and colleague journalists. However, not all media are using the same ways of communication with their audience and this can clearly be seen at first glance on their Twitter accounts.

The disadvantages of using Twitter in journalism are mostly related to the quality of selection of information and selection of sources that ultimately affect the credibility of the media content. One of the major changes that Twitter brought in journalistic practice refers to objectivity (Molyneux, 2015, p. 922). Objectivity, as one of the main characteristic of journalism, is facing the challenge of new technologies, and in this context Twitter. Although journalists are expected to provide the highest possible level of objectivity in reporting, in the world of Twitter, they are surrounded by fellow journalists and their personal, subjective views and attitudes as well as their audience that is more accessible than ever. The increasing availability and the amount of information on a daily basis has strengthened the audience and enabled it to see countless different sides of the same event, but with no guarantees of the quality and objectivity of specific media content (Rosen, 2006, 2010, as cited in Molyneux, 2015, p. 922). However, the loss of objectivity and impartiality on Twitter is manifested most through instant sharing of news via tweets without waiting to gather all information from other sources (Lasorsa et al., 2011; Lawrence et al., 2013, as cited in Molyneux, 2015, p. 923).

\section{Research methodology}

Research presented in this paper was conducted through analysis of tweets of the Croatian daily newspapers Jutarnji list and Večernji list. Most media in Croatia have a Twitter account, including the mentioned and analysed daily newspapers Jutarnji list and Večernji list. The selected newspapers, according to the Croatian Chamber of Commerce, are the most read and have the highest circulation. In the first place with the highest average selling is the tabloid newspaper 24 sata, which was not taken into account because the study included only serious, non-tabloid daily newspapers.

The main aim of the research is to determine ways of communication of Jutarnji list and Večernji list via Twitter. The specific aim is to examine whether there are similarities and differences

in the use of Twitter as a tool for publishing and sharing information and promotion of the two selected media. 


\subsection{Method, sample and research period}

The research was conducted by the method of content analysis of Twitter accounts. The accounts of Jutarnji list and Večernji list were analysed in the period of the last two weeks of May, 2016, namely from $17^{\text {th }}$ to $31^{\text {st }}$ May 2016. The analysis included all published tweets in that period. The mentioned research method is quantitative content analysis which can be defined as classification and quantification of all kinds of messages according to their content and pre-established rules (Zvonarević, 1981, p. 148, as cited in Labaš, Osmančević, 2014, p. 55). The unit of analysis was one tweet, and the research sample consisted of 661 tweets.

\subsection{Research questions and hypotheses}

The main hypothesis is:

Jutarnji list and Večernji list present differently their media content on Twitter.

Secondary hypotheses are:

1. Jutarnji list and Večernji list use hashtags in most of their tweets for the recognition and emphasis of key terms.

2. Jutarnji list and Večernji list use Twitter for live reporting directly from the scene of some events.

\subsection{Research matrix}

Tweets were analysed according to the research matrix which included general information about the analysed Twitter accounts, the data on territorial orientation of tweets, sources of information, the use of photographs, the presence of direct quotations, usage of hashtags, usage of live streaming, the presence of interactivity through communication with audience and the possible presence of sensationalism in tweets. 


\section{Results}

The following pages show the results of research. Some results will be presented through graphic tables.

\subsection{General information}

Both newspapers are active on Twitter and have official accounts. Jutarnji list joined Twitter in July 2008 under the name of Jutarnji list (@Jutarnjihr). The number of followers on 31 May 2016 was 100,333, and the number of tweets 28,774. Večernji list has been active on Twitter since February 2009 under the name Večernji list (@vecernji_list). The number of followers in the period of research was 99,002, and the number of tweets 60,288. In the period from $17^{\text {th }}$ May until 31 $1^{\text {st }}$ May, a total of 661 tweets, 157 from Jutarnji and 504 from Večernji list, were analysed. Already at the beginning, a significant difference in the number of tweets in the period of 15 days can be noticed.

\subsection{Topic}

In the research matrix possible topics of tweets were divided into politics, culture, sports, entertainment, crime section, comments and more. Both newspapers had the most tweets about politics. Jutarnji list had 95 and Večernji list 283 tweets about politics. Topics about sports were also frequent. Jutarnji list had 24 of them and Večernji 65. Jutarnji list had 11 tweets about tragedies, 9 tweets about culture, 1 comment, and 17 tweets that are classified as other. Večernji list had 61 tweets about tragedies and similar events, 44 tweets about culture and 51 tweets classified as other. The other category included various topics, such as reports from the National Weather Service or news that the strawberry season began. Table 1 shows the number of tweets classified by the main topic. 
Table 1: Tweets from Jutarnji list and Večernji list according to main topic $(\mathrm{N}=661)$

\begin{tabular}{|c|c|c|}
\hline \multicolumn{3}{|c|}{ TOPIC OF TWEET (N=661) } \\
\hline TOPIC & Jutarnji list & Večernji list \\
\hline Politics & 95 & 283 \\
\hline Culture & 9 & 44 \\
\hline Sports & 24 & 65 \\
\hline Tragedies & 11 & 61 \\
\hline Commentary & 1 & 0 \\
\hline Other & 17 & 51 \\
\hline TOTAL & 157 & 504 \\
\hline
\end{tabular}

\subsection{Territorial orientation of tweets}

In this category, both newspapers have similar results. The largest number of tweets according to territorial orientation comes from the City of Zagreb. Jutarnji list had 98 such tweets and Večernji list 267. Furthermore, Jutarnji list had 18 tweets which were associated with all of Croatia, 29 tweets referring to foreign countries, 6 tweets that included two or more Croatian counties, one tweet from Split-Dalmatia County, Dubrovnik-Neretva County, Primorje-Gorski Kotar County and Požega-Slavonia County. There were also two tweets from Šibenik-Knin County. Večernji list had 88 tweets that were associated with all of Croatia, 121 tweets which referred to foreign countries, 19 tweets that included two or more Croatian counties, 3 tweets from Split-Dalmatia County and Dubrovnik-Neretva County, two tweets from Istria County and 1 tweet from Osijek-Baranja County.

\subsection{Sources of information}

This category is dedicated to the sources of information that are essential in journalism mostly because the professional way of reporting is determined by showing all sides of an event so that the public could get a complete picture. If news has multiple relevant sources of information, it is more objective and has more credibility than the others (Malović, 2005, p. 37). Jutarnji list had 136 out of 157 tweets in which the source of information is mentioned, and Večernji list had 475 out of a total of 504 tweets which mentioned sources of information. These results show a positive trend with the main aim to achieve greater news credibility. 


\subsection{Photos in tweets}

People are mostly visual beings, so photos are a very useful tool in attracting attention on Twitter. However, in the analysis, there was a major difference in the way of presenting the content of Jutarnji and Večernji list on Twitter. The research matrix under the photograph category considered each tweet that besides text contained uploaded photo. Jutarnji list had 140 tweets with this characteristic and Večernji list had only 16 cases in which a tweet had both text and photo. However, Vecernji list had a lot of tweets with links in them and that was the case in all news that could be found in both the newspaper and news portal Večernji. Those links had thumbnails which contained photos but were not analysed in this category because the photo was not uploaded as it was only part of the link's thumbnail.

\subsection{Direct quotes}

In order to be more relevant and have more credibility, journalists often use direct quotes of people connected to some event they are reporting about. According to results, Jutarnji list had 103 out of the 157 tweets with direct quotations and Večernji list had them in 413 out of the 504 analysed tweets. Some examples are listed below:

Brkić: 'HDZ will make a statement about Karamarko after the decision of the Commission for conflict of interest'(23 May 2016 @jutarnjihr).

Watch gathering of "Vatreni" team in Zagreb! Their youngest member arrived first: 'I think that's in order' (20 May 2016, @jutarnjihr).

Ines Strenja-Linić: 'I will check the number of cases in which financial benefits for children with Down syndrome were taken away’ (17 May 2016, @vecernji_list).

Ostojić: 'There is no way that Božo Petrov or anyone else is being tracked illegally' (18 May 2016, @vecernji_list). 


\subsection{Hashtags}

As was mentioned in the theory part, Twitter is recognizable because of the use of hashtags (\#). Although it was assumed through the hypotheses that both daily newspapers use hashtags to enhance visibility and recognition of key terms in their tweets, this was, surprisingly, not the case. In fact, throughout the analysis only 7 tweets with hashtags were found, 4 from Jutarnji and 3 from Večernji list. The hashtags from Jutarnji were \#Torocaffe and \#MS804 (missing aeroplane from Malaysia Airlines). Večernji list only used the hashtag \#VLkolumna (short from Večernji list column). The results show that the analysed newspapers did not use one of the main characteristics of Twitter and thus failed in a possible attempt of getting closer to its users on Twitter. Examples of tweets with included hashtags are:

Why did the \#MS804 crash? It seems that it is not an act of terrorism, investigators have a new theory. (19 May 2016, @jutarnjihr).

The 'payoff' with Karamarko is not the job of Most or SDP but only of HDZ \#VLkolumna. (22 May 2016, @vecernji_list).

Table 2: Hashtags in tweets $(\mathrm{N}=661)$

\begin{tabular}{cccc} 
& \multicolumn{2}{c}{ HASHIAGS IN TWEETS (N=661) } & \\
& Jutarnji list & Večernji list & Hashtag \\
Yes & 4 & 3 & \#Torocaffe; \#MS804 \\
No & 153 & 501 & \#VLkolumna \\
Total & 157 & 504 &
\end{tabular}

\subsection{Inviting readers to comment}

In the analysis of 661 tweets from Jutarnji and Večernji list, no tweets were found which, with their content, invited readers to engage in commenting news. This way of tweeting is a reflection of the negative communication trend of Jutarnji and Večernji list especially because interaction between media and its audience is a very important part of journalism. 


\subsection{Live reporting}

One of the secondary hypotheses refers to live reporting of an event because that is also one of the benefits of Twitter. For its simplicity and brevity, tweets that media publish could inform the audience about some current event in a very fast way, and faster than any other media. But, surprisingly, this was not the case with Jutarnji and Večernji. Jutarnji list did not have any live tweets about some event, and Večernji only had 5 of them but all were about football matches. Examples of those tweets are below:

LIVE Sevilla beats Liverpool with three goals that shocked the Reds! (18 May 2016)

LIVE Atletico just equalized with Real Madrid! (28 May 2016)

\subsection{Sensationalism}

The last category of the research matrix referred to the presence of sensationalism in tweets. Some of the characteristics of sensationalism are dramatic titles, information based only on assumptions that may start to spread panic, putting information in a misleading or completely wrong context or drawing attention to irrelevant details (Skoko, Bajs, 2007, p. 97). In the analysis, found were 11 tweets of Jutarnji and 33 of Večernji list that had some characteristics of sensationalism. For example:

Panic in @HDZ001: 'We fear the fall of Karamarko @NLMost already has 4 or 5 votes!' (25 May 2016, @jutarnjihr).

Only in Croatia does it matter 'who your father is’(29 May 2016, @jutarnjihr)

Bomb was placed in plane while he was in Africa? (20 May 2016, @vecernji_list).

Abortion is not killing Croats, something else is! (23 May 2016, @vecernji_list).

New molecules killing melanoma cells? (28 May 2016, @vecernji_list). 


\subsection{Confirmation and negation of the hypotheses}

To repeat, the main hypothesis of the research was:

Jutarnji list and Večernji list present differently their media content on Twitter.

Secondary hypotheses were:

1. Jutarnji list and Večernji list use hashtags in most of their tweets for the recognition and emphasis of key terms.

2. Jutarnji list and Večernji list use Twitter for live reporting directly from the scene of some events.

The main hypothesis was confirmed because both, Jutarnji and Večernji list had different approaches of reporting and presenting their content on Twitter. The format of tweets from Jutarnji consists of a short title, shortened links and attached photo related to the content. On the other hand, Večernji list in most of its tweets used a short text without a title and with a large thumbnail of the attached link but rarely with attached photo that is not part of a link.

The first secondary hypothesis was refuted because of the 661 analysed tweets only 7 of them had hashtags. From those results it can be concluded that neither Jutarnji nor Večernji list used the benefits of Twitter or recognized the opportunities of using hashtags in tweets in order to upgrade their communication strategies and relations with audiences.

The other secondary hypothesis was also refuted because of the total of 661 analysed tweets, only 5 of them were part of live reporting of some event, and in this case, only football matches. Live reporting is also one of many advantages of using Twitter, and Jutarnji and Večernji did not use it enough. 


\section{Conclusion}

New communication technologies have brought with them numerous, mostly positive changes. Twitter is one of the most popular social networks, both in Croatia and other countries and it is becoming increasingly popular in journalism. Almost all media and a large number of journalists can be found on Twitter through their official accounts. For the purpose of this paper, research was carried out in order to identify similarities and differences in communication on Twitter by Jutarnji and Večernji list. The results showed that both newspapers in most cases posted tweets about different political topics or sports. The largest number of tweets in both newspapers referred to the City of Zagreb, and then to the entire country, and the number of tweets that mentioned only one particular county was rare. Jutarnji and Večernji list have different approaches to presenting their content to the audience, which is visible through the format of their tweets. As Jutarnji list also attached a large format photo with the textual part of the tweet, in most cases, Večernji attached a link with the textual part.

Neither Jutarnji nor Večernji list recognized or used all of the advantages of Twitter in journalism and the presentation of media content in order to increase visibility and strengthen the connections with audience. This primarily refers to the use of hashtags and live reporting because, according to the results, only 7 out of 661 tweets had hashtags and only 5 out of 661 tweets were part of live reporting. Both newspapers could and should increase the level of their communication strategy while using Twitter. Their presentation of content could be a lot more professional and adjusted to Twitter characteristics than they are now.

Society at all levels needs media literacy to improve and create the foundation for responsible citizens and media users who critically think about media content that surrounds them. Although many European countries have recognized media literacy as one of the most important competencies of the $21^{\text {st }}$ century, in Croatia, it has still not reached a sufficiently high level. This type of literacy is essential for all people, including journalists and their audiences. Due to the increasing progress of new technologies, the way in which media functions also needs to adjust and develop according to changes, not only in the technological but also in the political, cultural and social context. 


\section{Reference List}

- Armstrong, C. L., Gao, F. (2010). Now tweet this how news organizations use twitter. Electronic News, 4 (4), 218-235.

- Artwick, C. G. (2014). News sourcing and gender on Twitter. Journalism, 15 (8), 1111-1127.

- Barnard, S. R. (2016). “Tweet or be sacked”: Twitter and the new elements of journalistic practice. Journalism, 17 (2), $190-207$.

- Brautović, M. (2011). Upotreba Twittera za promociju sadržaja i uspostavu dvosmjerne komunikacije s korisnicima kod hrvatskih online medija. Communication Management Quarterly, 20 (6), 61-72.

- Bruns, A., Highfield, T., Lind, R. A. (2012). Blogs, Twitter, and breaking news: The produsage of citizen journalism. Produsing theory in a digital world: The intersection of audiences and production in contemporary theory, 80, 15-32.

- Car, V., Turčilo, L., Matović, M. (2015). Medijska pismenost kao jedan od preduvjeta odgovornosti medija. In: Car, V., Turčilo, L., Matović, M. (Eds.), Medijska pismenost - preduvjet za odgovorne medije (pp. 1-3). Sarajevo: Fakultet političkih nauka.

- Chaudron, S. (2015). Young Children (0-8) and Digital Technology. Joint Research Centre, European Comission, Luxembourg: Publications Office of the European Union.

- David, G. (2010). Camera phone images, videos and live streaming: a contemporary visual trend. Visual Studies, 89-98.

- Dwyer, R., Fraser, S. (2016). Addicting via Hashtags How Is Twitter Making Addiction?. Contemporary Drug Problems, 43 (1), $79-97$.

- Goggin, G. (2013) Youth culture and mobiles. Mobile Media and Communication, 1 (1), 83-88.

- Gruzd, A., Wellman, B., Takhteyev, Y. (2011). Imagining Twitter as an imagined community. American Behavioral Scientist, 55 (10), 1294-1318.

- Haddon, L. (2013) Mobile media and children. Mobile Media and Communication 1 (1), 89-95.

- Hermida, A. (2012). Tweets and truth: Journalism as a discipline of collaborative verification. Journalism Practice, 6 (5-6), 659-668.

- Hermida, A. (2015). Power Plays on Social Media. Social Media+ Society, 1 (1), 1-2.

- Jenkins, H., Ford, S., Green, J. (2013). Spreadable media: Creating value and meaning in a networked culture. New York, London: NYU Press.

- Jenkins, H., Purushotma, R., Weigel, M., Clinton, K., Robison, A. J. (2009). Confronting the challenges of participatory culture: Media education for the 21st century. Cambridge, Massachusetts; London, England: The MIT Press.

- Labaš, D., Osmančević, L. (2014). Dječji domovi u hrvatskom tisku u 2012. godini: Analiza Jutarnjeg lista i Večernjeg lista. Medijske studije, 5 (10), 51-66.

- Malović, S. (2005). Osnove novinarstva. Zagreb: Golden marketing - Tehnička knjiga.

- Mitchelstein, E., Boczkowski, P. J. (2009). Between tradition and change A review of recent research on online news production. Journalism, 10 (5), 562-586.

- Molyneux, L. (2015). What journalists retweet: Opinion, humor, and brand development on Twitter. Journalism, 16 (7), 920 -935.

- Pew Research Center (2016). News Use Across Social Media Platforms 2016. Retrieved from: http://www.journalism.org/2016/05/26/ news-use-across-social-media-platforms-2016/. December 02, 2016.

- Skoko, B., Bajs, D. (2007). Objavljivanje neistina i manipuliranje činjenicama u hrvatskim medijima i mogućnosti zaštite privatnosti, časti i ugleda. Politička misao, XLIV (1), 93-116.

- Statista (2016). Most famous social network sites worldwide as of September 2016, ranked by number of active users (in millions). Retrieved from: http://www.statista.com/statistics/272014/global-social-networks-ranked-by-number-of-users/. December 01, 2016.

- UNESCO (1999). Guidelines for media education. Presented at international conference Educating for the Media and the Digital Age. Vienna, Austria.

- Veltri, G. A. (2012). Microblogging and nanotweets: Nanotechnology on Twitter.Public Understanding of Science, 22 (7), $832-849$.

- Zvonarević, M. (1981.) Socijalna psihologija. Zagreb: Školska knjiga. 


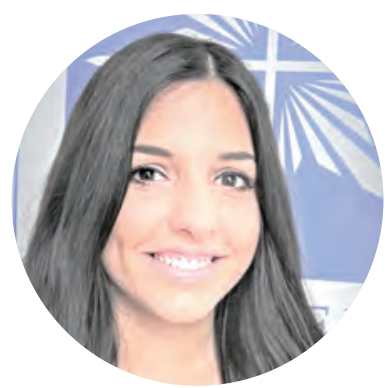

\section{Leali Osmančević}

Leali Osmančević is a teaching assistant at the Department of Communication Sciences at the Catholic University of Croatia, external assistant at the University of Zagreb's Center for Croatian Studies and a $\mathrm{PhD}$ candidate in Communication and Information Sciences at the postgraduate Doctoral Study Programme in Communication and Information Sciences, Faculty of Humanities and Social Sciences, University of Zagreb. She is the author of several scientific papers in the field of media and children and media education. She is a member of the Steering Committee at the Association for Communication and Media Culture, where she was coordinator of educational lectures and workshops for children and adults in the field of media literacy and peer violence prevention. Her research interests are children and media, media ethics, media literacy and interpersonal communication. 